\title{
The Handling of Sugarcane Trash in the Humid Areas of Puerto Rico
}

\author{
G. Samuels, E. González-T'ejera, and S. Alers-Alers'
}

\section{INTRODUCTION}

Sugarcane trash is the material left on the surface of the ground after harvest. It consists of all the leaves and the upper immature part of the stalk. Hardy and Evans (3)2 estimated that a ton of trash was produced for every 4 tons of green millable cane. In 1963, when 10,122,518 tons of cane were milled in Puerto Rico, with an average acre-yield of 30.8 tons (2), this meant the disposal of almost 8 tons of dry sugarcane trash containing 93 pounds of combined nitrogen per acre $(6)$. If handled properly, this trash becomes an asset; if misused, it can become a liability to the sugarcane grower.

The handling of trash in sugarcane fields is an essential part of the agronomic practices of growing sugarcane. Utilization of the trash presents practical difficulties. Most sugarcane growers in Puerto Rico, Hawaii, and Louisiana simply burn it to facilitate cutting of the sugarcane. The trash is very bulky and is difficult to plow under for a new crop, or to manage in the cultivation of the ratoon crop. If it is buried or plowedunder deeply, decomposition may be too slow, and the effective use of soil nitrogen is hindered. Should the trash remain undecomposed, it may serve to protect the dormant stage of insects injurious to the cane, and under conditions of excessive moisture and low temperatures, its presence may increase the infection of cane by facultative parasitic soil fungi.

Bonnet et al. (1), compared the effect of leaving the trash as a mulch or burning it for four crops of sugarcane (1944-48) grown in a lateritic soil with a 40-percent slope. No significant differences in yields were found between treatments. Highly significant differences, however, were found in soil losses, the unmulched plots losing about 11 times more soil than the mulched ones. Samuels et al. (8), found that yields of sugar per acre were not significantly decreased in the first four ratoon crops, but in the fifth and sixth ratoons yields were significantly decreased when comparing burned to aligned trash treatments on a Vega Alta silty clay at Río Piedras.

Landrau et al. (4), reported no significant differences in sugarcane yields after 5 years (1947-52) attributable to aligning, aligning and furrowing,

1 Agronomist, Assistant Agronomist, and Assistant Agronomist, respectively, Agricultural Experiment Station, University of Puerto Rico, Río Piedras, P.R. The authors thank the personnel of the Experiment Station, past and present, for their cooperation during the 18 years of this study.

2 Italic numbers in parentheses refer to Literature Cited, p. 87. 
burning, or not disturbing the trash. Samuels et al. (7), showed that leaving the cane trash undisturbed and applying the fertilizer over the cane trash compared favorably with aligning trash in alternate banks with or without furrowing.

It is the purpose of this paper to report an experiment designed to determine the best method of trash disposal for sugarcane growing in the Humid Cane Area of Puerto Rico.

\section{PROCEDURES}

To determine the effects of different methods of handling the trash on yields of sugarcane, an experiment was undertaken at Río Piedras on Vega Baja silty clay. The experiment was planted on June 21, 1944, with sugarcane variety P.O.J. 2878. The procedures for the handling of the trash for each treatment were as follows:

Trash burned: After harvesting the cane, the trash was gathered toward the center of the plot and then burned.

Trash buried: A furrow was made about 1 foot deep between rows; the trash was placed in the furrow and covered with soil.

Trash aligned: The trash was aligned in alternate banks or rows.

The treatments were repeated every year after harvest. The first cycle with P.O.J. 2878 continued for 10 ratoons. In 1955, the experiment was replanted to sugarcane variety $H .328560$ and continued for three ratoons. Finally, in 1959, the experiment was replanted to P.R. 980 and continued for a plant crop and one ratoon.

The experiment consisted of a simple randomized block in which each treatment was replicated 20 times on plots 150 feet long by 20 feet wide, with cane rows 4 feet apart. The field as a whole received an application of 1,200 pounds of a $15-3-10$ fertilizer every year.

In 1955, the senior author found that poor drainage had been affecting the yields of several replications in one portion of the field. Analyses of variance were made of the first 10 harvests eliminating 3,6 , and 9 replications that could have been influenced by the poor soil drainage. Increase in precision was found to be highest when nine replications were eliminated. The work reported herein is based on 11 replications of each treatment for the first cycle of plant crop and 10 ratoons and the second cycle of a plant crop and three ratoons. The third cycle of a plant crop and one ratoon has five replications.

\section{RESULTS}

AVAILABLE $96^{\circ}$ SUGAR PER ACRR

The yields of available $96^{\circ}$ sugar per acre for the various methods of handling the cane trash are given in table 1 . In general, the highest yields 
TABLE 1. The influence of the handling of sugarcane trash on the mean yield in tons of available $96^{\circ}$ sugar per acre

\begin{tabular}{|c|c|c|c|c|c|c|c|c|c|c|c|}
\hline \multirow{2}{*}{ Treatments } & \multicolumn{11}{|c|}{ Yield of available $96^{\circ}$ sugar, tons per acre, for- Girst cycle (P.O.J. 2878) } \\
\hline & $\begin{array}{l}\text { Plant } \\
\text { cane }\end{array}$ & $\underset{\text { ratoon }}{\text { First }}$ & $\begin{array}{l}\text { Secor } \\
\text { ratoo }\end{array}$ & $\begin{array}{l}\text { Third } \\
\text { ratoon }\end{array}$ & $\begin{array}{l}\text { Fourth } \\
\text { ratoon }\end{array}$ & $\begin{array}{l}\text { Fifth } \\
\text { ratoon }\end{array}$ & $\underset{\text { Satoon }}{\text { Sixth }}$ & $\begin{array}{l}\text { Seventh } \\
\text { ratoon }\end{array}$ & $\underset{\text { ratoon }}{\text { Eighth }}$ & $\begin{array}{l}\text { Ninthl } \\
\text { ratoon }\end{array}$ & $\begin{array}{c}\text { Tenth } \\
\text { ratoon }\end{array}$ \\
\hline $\begin{array}{l}\text { Trash burned } \\
\text { Trash buried } \\
\text { Trash aligned }\end{array}$ & $\begin{array}{l}3.01 \\
2.90 \\
2.94\end{array}$ & $\begin{array}{l}5.32 \\
5.30 \\
5.30\end{array}$ & $\begin{array}{l}6.97 \\
6.52 \\
6.83\end{array}$ & $\begin{array}{l}5.66 \\
5.57 \\
5.36\end{array}$ & $\begin{array}{l}5.49 \\
5.53 \\
5.18\end{array}$ & $\begin{array}{l}5.83 \\
5.76 \\
6.11\end{array}$ & $\begin{array}{l}4.82 \\
4.81 \\
4.96\end{array}$ & $\begin{array}{l}5.04 \\
5.19 \\
5.53\end{array}$ & $\begin{array}{l}4.70 \\
4.99 \\
5.11\end{array}$ & $\begin{array}{l}6.15 \\
6.68 \\
7.02\end{array}$ & $\begin{array}{l}3.75 \\
4.35 \\
4.49\end{array}$ \\
\hline \multirow[t]{3}{*}{$\begin{array}{l}\text { Least significant diff } \\
\text { at: } \\
\text { 5-percent level } \\
\text { 1-percent level }\end{array}$} & N.s.d & N.s.d & $\begin{array}{r}0.37 \\
.51\end{array}$ & N.s.d & N.s.d & N.s.d & N.s.d & $\begin{array}{r}0.437 \\
.596\end{array}$ & $\begin{array}{r}0.584 \\
.796\end{array}$ & $\begin{array}{r}0.095 \\
.385\end{array}$ & $\begin{array}{r}0.349 \\
.475\end{array}$ \\
\hline & \multicolumn{5}{|c|}{ Second cycle (H. 328560) } & \multicolumn{6}{|c|}{ Third cycle (P.R. 980)2 } \\
\hline & Plant cane & First ratoon & \multicolumn{2}{|c|}{ Second ratoon } & Third ratoon & \multicolumn{2}{|c|}{ Plant cane } & \multicolumn{2}{|c|}{ First ratoon } & \multicolumn{2}{|c|}{ Average of 17 crops } \\
\hline $\begin{array}{l}\text { Trash burned } \\
\text { Trash buried } \\
\text { Trash aligned }\end{array}$ & $\begin{array}{l}6.57 \\
6.93 \\
6.36\end{array}$ & $\begin{array}{l}2.18 \\
2.23\end{array}$ & & $\begin{array}{l}6.59 \\
6.89\end{array}$ & $\begin{array}{l}4.82 \\
5.79 \\
6.21\end{array}$ & \multicolumn{2}{|c|}{$\begin{array}{l}4.06 \\
4.11\end{array}$} & $\begin{array}{l}7.4 \\
7.0 \\
8.5\end{array}$ & & $\begin{array}{l}5 . \\
5 . \\
5 .\end{array}$ & \\
\hline $\begin{array}{l}\text { Least significant diff } \\
\text { at: } \\
\text { 5-percent level } \\
\text { 1-percent level }\end{array}$ & N.s.d & N.s.d & \multicolumn{2}{|r|}{$\begin{array}{r}0.518 \\
.707\end{array}$} & $\begin{array}{r}0.412 \\
.562\end{array}$ & \multicolumn{2}{|c|}{ N.s.d } & \multicolumn{2}{|c|}{$\begin{array}{r}0.271 \\
.395\end{array}$} & \multicolumn{2}{|c|}{$\begin{array}{r}0.408 \\
.577\end{array}$} \\
\hline
\end{tabular}

${ }^{3}$ N.s.d. = no significant difference between treatments.

2 Only 5 replications as compared to 11 replications for other 2 cycles. 
were obtained for the trash-aligned treatment. In none of the crops harvested did burning or burying the trash give yields significantly better than those for the aligned trash. However, for many of the crops the burned- or buried-trash treatments gave significantly lower yields of sugar than the aligned-trash treatment.

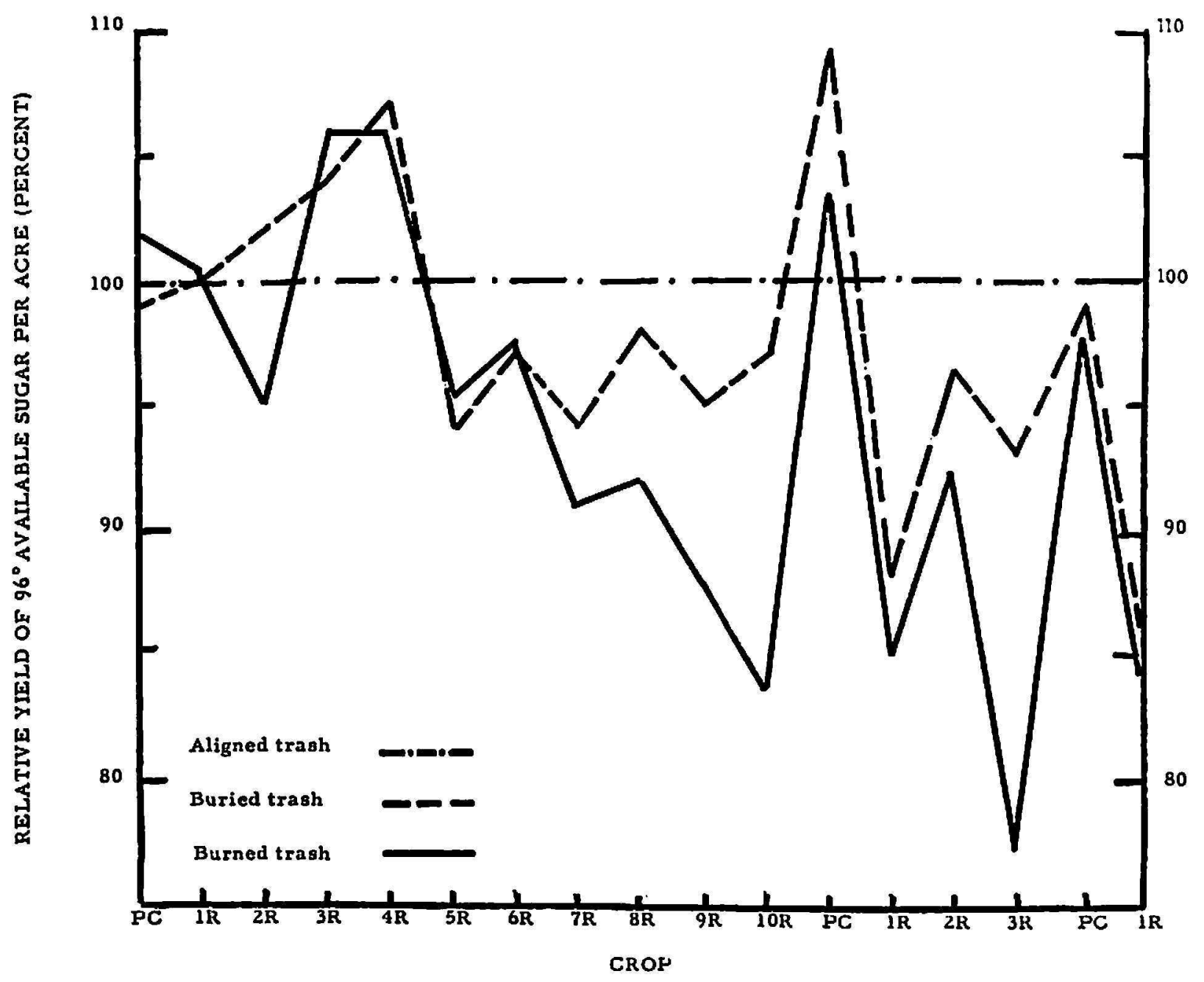

Fia. 1.-The percentage relative yields of $96^{\circ}$ available sugar per acre as influenced by method of trash-handling.

No detrimental effect was seen from burning the cane trash instead of aligning until the seventh ratoon of the first cycle, 8 years from time of planting. The reduction of sugar per acre due to burning tended to increase as the number of ratoons increased (see figure 1). The burned-trash yields were 0.28 ton per acre lower than the aligned trash for the fifth ratoon; by the tenth ratoon, this difference had increased to 0.74 ton per acre.

When the ratoon crops were plowed under and a new crop of cane was planted, the differences in yields from burning the sugarcane trash disappeared. The plant crop and first ratoon of the second cycle (table 1) showed 
no significant differences in yields between burning or aligning the trash, despite the fact that the tenth ratoon crop of the previous cycle had significantly lower yields from burning. However, by the second ratoon of the second cycle, the burned-trash treatment had significantly lower yields when compared to aligning. This difference became even more pronounced by the third ratoon, when 1.39 tons per acre less sugar was obtained when burning the trash as compared to aligning (table 1).

Once again differences associated with methods used in handling the cane trash disappeared when the ratoon crop was plowed under and a new crop was planted in the third cycle. However, the first ratoon of the third cycle already showed lower yields due to burning the cane trash. The yield was 1.43 tons of sugar per acre less from burning the trash versus aligning. This was the largest difference obtained in the 17 crops of the experiment.

The burying of the sugarcane trash gave results somewhat intermediate between those from aligning or burning it (table 1 and fig. 1). There were no significant differences in any of the treatments for the first six ratoons, except for the third. Beginning with the seventh ratoon, the burying of the trash began to produce declines in yields as compared to aligning the trash. These yield declines were not quite as severe as encountered with burning the trash. It was found when burning the cane that the buried-trash plots showed recovery when new plantings were made (fig. 1).

\section{SUCROSE-PERCENT-CANE}

No consistent differences in the sucrose-percent-cane values were found attributable to the method of trash-handling (table 2). Only 2 of the 17 crops of the experiment, showed any significant differences in their sucrosepercent-cane values, and these were not the same for both crops. We can assume that burning, burying, or aligning the trash did not influence the sucrose content of the sugarcane in this experiment. Similar results have been obtained in other experiments (8).

\section{TONS OF CANE PER ACRE}

There. were significant differences in tons of cane per acre due to the method of trash handling (table 3). The differences between the burning and trash-aligned treatments did not occur as soon for tons of cane as it did for tons of sugar per acre in the first cycle. The plant cane of the second cycle did not display a recovery in tons of cane in the burned-trash treatment following the planting of a new crop, as was found for the same treatment in regards to tons sugar per acre. However, the third-cycle plant cane did show a recovery under the burned-trash treatment as compared to the depressed yields obtained in the ratoon crop before plowing and planting. 
TABLE 2.-The influence of handling sugarcane trash on the mean yield of sucrose-percent-cane

\begin{tabular}{|c|c|c|c|c|c|c|c|c|c|c|c|}
\hline \multirow{2}{*}{ Treatments } & \multicolumn{11}{|c|}{ Yields of sucrose-percent-cane, for-6irst cycle (P.0.J. 2878) } \\
\hline & $\begin{array}{c}\text { Plant } \\
\text { cane }\end{array}$ & $\underset{\text { ratoon }}{\text { First }}$ & $\begin{array}{l}\text { Second } \\
\text { ratoon }\end{array}$ & $\underset{\text { ratoon }}{\text { Third }}$ & $\begin{array}{l}\text { Fourth } \\
\text { ratoon }\end{array}$ & $\begin{array}{l}\text { Fifth } \\
\text { ratoon }\end{array}$ & $\begin{array}{l}\text { Sixth } \\
\text { ratoon }\end{array}$ & $\begin{array}{c}\text { Seventh } \\
\text { ratoon }\end{array}$ & $\begin{array}{l}\text { Eighth } \\
\text { ratoon }\end{array}$ & $\begin{array}{l}\text { Ninth } \\
\text { ratoon }\end{array}$ & $\begin{array}{l}\text { Tenth } \\
\text { ratoon }\end{array}$ \\
\hline $\begin{array}{l}\text { Trash burned } \\
\text { Trash buried } \\
\text { Trash aligned }\end{array}$ & $\begin{array}{l}10.14 \\
10.13 \\
10.33\end{array}$ & $\begin{array}{l}10.33 \\
10.60 \\
10.40\end{array}$ & $\begin{array}{l}12.43 \\
12.52 \\
12.62\end{array}$ & $\begin{array}{l}12.48 \\
12.47 \\
12.23\end{array}$ & $\begin{array}{l}12.58 \\
12.75 \\
12.17\end{array}$ & $\begin{array}{l}12.99 \\
13.08 \\
13.26\end{array}$ & $\begin{array}{l}13.05 \\
13.07 \\
12.91\end{array}$ & $\begin{array}{l}11.07 \\
11.56 \\
11.88\end{array}$ & $\begin{array}{l}12.92 \\
13.40 \\
13.17\end{array}$ & $\begin{array}{l}13.10 \\
13.64 \\
13.76\end{array}$ & $\begin{array}{l}13.54 \\
13.82 \\
13.54\end{array}$ \\
\hline \multirow[t]{3}{*}{$\begin{array}{l}\text { Least significant dif- } \\
\text { ference }{ }^{1} \text { at: } \\
\text { 5-percent level } \\
\text { 1-percent level }\end{array}$} & N.s.d. & N.s.d. & N.s.d. & N.s.d. & N.s.d. & N.s.d. & N.s.d. & N.s.d. & N.s.d. & $\begin{array}{r}0.54 \\
.74\end{array}$ & N.s.d. \\
\hline & \multicolumn{6}{|c|}{ Second cycle (H. 328560) } & \multicolumn{5}{|c|}{ Third cycle (P.R. 980)2 } \\
\hline & Plant cane & \multicolumn{2}{|c|}{ First ratoon } & Second ratoon & \multicolumn{2}{|c|}{ Third ratoon } & Plant cane & \multicolumn{2}{|c|}{ First ratoon } & \multicolumn{2}{|c|}{ Average of 17 crops } \\
\hline $\begin{array}{l}\text { Trash burned } \\
\text { Trash buried } \\
\text { Trash aligned }\end{array}$ & $\begin{array}{l}12.50 \\
12.75 \\
11.58\end{array}$ & \multicolumn{2}{|c|}{$\begin{array}{r}9.79 \\
9.91 \\
10.44\end{array}$} & $\begin{array}{l}13.30 \\
13.63 \\
13.00\end{array}$ & \multicolumn{2}{|c|}{$\begin{array}{l}13.46 \\
13.61 \\
14.44\end{array}$} & $\begin{array}{l}11.08 \\
11.29 \\
11.36\end{array}$ & \multicolumn{2}{|c|}{$\begin{array}{l}11.50 \\
11.18 \\
11.72\end{array}$} & \multicolumn{2}{|c|}{$\begin{array}{l}12.15 \\
12.30 \\
12.33\end{array}$} \\
\hline $\begin{array}{l}\text { Least significant dif- } \\
\text { ference }{ }^{1} \text { at: } \\
\text { 5-percent level } \\
\text { 1-percent level }\end{array}$ & $\begin{array}{r}.84 \\
1.14\end{array}$ & \multicolumn{2}{|c|}{ N.s.d. } & N.s.d. & \multicolumn{2}{|c|}{$\begin{array}{l}.62 \\
.85\end{array}$} & N.s.d. & \multicolumn{2}{|c|}{ N.s.d. } & \multicolumn{2}{|c|}{ N.s.d. } \\
\hline
\end{tabular}

${ }^{1}$ N.s.d. = no significant difference between treatments.

2 Only 5 replications as compared to 11 replications for other 2 cycles. 
TABLE 3.-The influence of handling sugarcane trash on the mean yield in tons of cane per acre

\begin{tabular}{|c|c|c|c|c|c|c|c|c|c|c|c|}
\hline \multirow{2}{*}{ Treatments } & \multicolumn{11}{|c|}{ Yield of sugarcane, tons per acre, for-first cycle (P.O.J. 2878) } \\
\hline & $\begin{array}{l}\text { Plant } \\
\text { canc }\end{array}$ & $\underset{\text { ratoon }}{\text { First }}$ & $\begin{array}{l}\text { Second } \\
\text { ratoon }\end{array}$ & $\begin{array}{c}\text { Third } \\
\text { ratoon }\end{array}$ & $\begin{array}{l}\text { Fourth } \\
\text { ratoon }\end{array}$ & $\underset{\text { Faftoon }}{\text { Fifth }}$ & $\underset{\text { ratoon }}{\text { Sixth }}$ & $\begin{array}{l}\text { Seventh } \\
\text { ratoon }\end{array}$ & $\underset{\substack{\text { Eighth } \\
\text { ratoon }}}{ }$ & $\underset{\text { Natoon }}{\text { Ninth }}$ & $\begin{array}{l}\text { Tenth } \\
\text { ratoon }\end{array}$ \\
\hline $\begin{array}{l}\text { Trash burned } \\
\text { Trash buried } \\
\text { Trash aligned }\end{array}$ & $\begin{array}{l}29.73 \\
28.64 \\
28.55\end{array}$ & $\begin{array}{l}51.50 \\
50.00 \\
51.00\end{array}$ & $\begin{array}{l}56.05 \\
52.15 \\
54.15\end{array}$ & $\begin{array}{l}45.32 \\
44.63 \\
43.83\end{array}$ & $\begin{array}{l}43.63 \\
43.41 \\
42.53\end{array}$ & $\begin{array}{l}44.89 \\
44.02 \\
46.04\end{array}$ & $\begin{array}{l}36.94 \\
36.84 \\
38.45\end{array}$ & $\begin{array}{l}45.49 \\
44.93 \\
46.51\end{array}$ & $\begin{array}{l}36.41 \\
37.26 \\
38.83\end{array}$ & $\begin{array}{l}47.00 \\
49.00 \\
51.00\end{array}$ & $\begin{array}{l}27.73 \\
31.45 \\
33.28\end{array}$ \\
\hline \multirow[t]{3}{*}{$\begin{array}{l}\text { Least significant dif- } \\
\text { ference at }{ }^{1} \text { : } \\
\text { 5-percent level } \\
\text { 1-percent level }\end{array}$} & N.s.d. & N.s.d. & $\begin{array}{l}3.05 \\
4.16\end{array}$ & N.s.d. & N.s.d. & N.s.d. & N.s.d. & $\begin{array}{l}1.51 \\
2.06\end{array}$ & N.s.d. & $\begin{array}{l}2.27 \\
3.09\end{array}$ & $\begin{array}{l}2.26 \\
3.08\end{array}$ \\
\hline & \multicolumn{6}{|c|}{ Second cycle (H-328560) } & \multicolumn{5}{|c|}{ Third cycle (P.R. 980)2 } \\
\hline & Plant cane & \multicolumn{2}{|c|}{ First ratoon } & Second ratoon & \multicolumn{2}{|c|}{ Third ratoon } & Plant cane & \multicolumn{2}{|c|}{ First ratoon } & \multicolumn{2}{|c|}{ Average of 17 crops } \\
\hline $\begin{array}{l}\text { Trash burned } \\
\text { Trash buried } \\
\text { Trash aligned }\end{array}$ & $\begin{array}{l}52.58 \\
54.33 \\
54.92\end{array}$ & \multicolumn{2}{|c|}{$\begin{array}{l}22.29 \\
22.46 \\
24.23\end{array}$} & $\begin{array}{l}49.58 \\
50.58 \\
54.87\end{array}$ & \multicolumn{2}{|c|}{$\begin{array}{l}35.77 \\
42.51 \\
42.99\end{array}$} & $\begin{array}{l}36.60 \\
36.36 \\
36.45\end{array}$ & \multicolumn{2}{|c|}{$\begin{array}{l}65.00 \\
68.00 \\
76.00\end{array}$} & \multicolumn{2}{|c|}{$\begin{array}{l}42.20 \\
43.23 \\
44.80\end{array}$} \\
\hline $\begin{array}{l}\text { Least significant dif- } \\
\text { ference at }{ }^{1} \text { : } \\
\text { 5-percent level } \\
\text { 1-percent level }\end{array}$ & $\begin{array}{l}1.95 \\
2.66\end{array}$ & \multicolumn{2}{|c|}{ N.s.d. } & $\begin{array}{l}2.91 \\
3.97\end{array}$ & \multicolumn{2}{|c|}{$\begin{array}{l}2.26 \\
3.08\end{array}$} & N.s.d. & \multicolumn{2}{|c|}{$\begin{array}{l}5.07 \\
7.38\end{array}$} & & \\
\hline
\end{tabular}

2 Only 5 replications as compared to 11 replications for other 2 cycles. 
The greatest losses in tons of cane comparing burning to aligning trash were always encountered in the last ratoon of each cycle. The losses were 5.85 tons for the tenth ratoon of the first cycle, 5.29 tons for the third ratoon of the second, and 8.00 tons for the first ratoon of the third cycle.

The burying of the sugarcane trash gave results somewhat intermediate between those for aligning the cane trash or burning it (table 3). There were no significant differences in any of the treatments for the first six ratoons except for the third. Beginning with the seventh ratoon, the burying of the trash began to produce declines in yields of cane as compared to aligning the trash. These yield declines were not quite as severe as were encountered with burning the trash.

\section{DISCUSSION}

The burning of the sugarcane trash caused a decrease in sugar yields for the 17 crops of the experiment. In the first few years these differences were not appreciable as judged by yield data. After 7 years of continuous cultivation the burning of the trash significantly depressed sugar yields, and continued to do so at a greater rate until the ratoon was plowed under. After plowing of the old ratoon and planting a new crop, the detrimental factors involved in burning the trash were corrected, and yields became similar to those of the trash-aligned treatment. The "rejuvenation" of yields of cane obtained by plowing the cane plots where trash had been burned year after year lasted for a short time only-until the first ratoon for the second cycle and for the plant crop of the third cycle.

What factor or factors are responsible for the rejuvenation of the yields on the burned-trash treatment plots by plowing and planting a new crop? On first thought one could say that the incorporation of the organic material from the roots and stubble of the ratoon crop by plowing replaced the supply of organic matter depleted by burning the cane trash. However, our buriedtrash treatment returns organic matter to the soil at every harvest, and yet yields of sugar from this trash treatment were not equal to those from the trash-aligned treatment, and in many cases were similar to those from the trash-burned treatment.

In the heavy soils of the Humid Cane Area, the burying of the trash has both good and bad features. Burying the trash is not cheaper than aligning it. The incorporation of the organic material into a poorly drained soil may create harmful conditions, if insufficient aeration is present for proper oxidation of this incorporated organic material. Analyses of soil samples taken from the various treatments indicate that the $\mathrm{C} / \mathrm{N}$ ratio for the trash-buried treatment was higher than for the other trash treatments (table 4). All these ratios considered together were less than 10:1, which indicates that the trash decomposed quickly. However, the 0-6- 
inch $\mathrm{C} / \mathrm{N}$ ratio for the buried-trash plot was very close to 10:1, and trash decomposition was not as rapid as for the other treatments.

If organic matter was not responsible for the rejuvenation of the yields on trash-burned treatment plots upon plowing, what other factors merit attention? The aeration of the soil brought about by plowing should be considered. The Vega Baja silty clay used in this experiment, in common with most of the heavy soils of the humid cane areas, suffers from poor drainage during a great portion of the growing period. Such soil definitely benefits from aeration created by plowing. The benefit derived from aeration of the soil is short-lived, as once again these heavy soils begin to compact. Martínez and Lugo-Lopez (5), working on a Caguas silt loam in humid eastcentral Puerto Rico, found that the beneficial effect of aeration of a subsoil on sugar yields in the plant crop disappeared with the first ratoon.

Previous soil studies (8) conducted after the sixth ratoon crop was

TABLE 4.-The $C / N$ ratio of soil from the sugarcane trash-handling experiment at Rio Piedras

\begin{tabular}{c|c|c|c}
\hline \multirow{2}{*}{ Trealments of trash } & \multicolumn{3}{|c}{ C/N ratio for soil depths of- } \\
\cline { 2 - 4 } & $0-6$ inches & $6-12$ inches & $12-18$ inches \\
\hline Burned & 9.2 & 6.8 & 3.3 \\
Buried & 9.9 & 8.0 & 4.9 \\
Aligned & 9.2 & 6.1 & 3.7 \\
\hline
\end{tabular}

harvested indicated no significant difference between $\mathrm{pH}$ and total-nitrogen values for the various treatments. Similar results were obtained from soil samples analyzed after the sixteenth crop. The sampling after the sixth ratoon crop revealed a significantly lower organic-matter content of trashburned plots than that of the buried or aligned-trash plots (8). Such differences were not evident for the soils samples after the sixteenth crop.

Comment must be made on the procedure used in the trash-burned plots. The trash was gathered together in the center of the plot and burned. When this experiment began, in 1944, the common field practice was to burn cane trash after harvest. Beginning in the 1950's, the cane trash in commercial fields was burned while the cane was standing, just prior to cutting the cane. This practice of burning standing cane could not be adapted to the existing experiment.

The burning of the cane trash after harvest is much more drastic in its destruction of organic material left on the soil than that of burning the standing cane. The standing cane is fired usually the evening of the day before harvest, or early the morning of the day of harvest. The fire con- 
sumes the dead and dying older leaves of the cane plant. Still remaining are the green tops. These tops are cut off the cane at harvest, and remain in the field to decay and become part of the soil organic matter.

Thus the trash-burning treatment used in this experiment is the most severe of any burning practice and is no longer in common use. It would be expected that the detrimental effects of the trash-burned treatment found in this experiment would be modified by present commercial burning practices. However, this does not mean that the burning of sugarcane trash cannot cause lower yields of sugar. The speed of the decline in yields from burning of standing cane is now being studied in a new series of experiments by this Agricultural Experiment Station.

The burying or burning of the trash produced no increase in yields and, over a period of years, gave lower yields than the practice of aligning trash. Burning is cheaper than aligning or burying, but continued burning lowers yields, increases soil erosion, and results in higher weeding costs. Yet, labor costs and practices dictate the economics of the need for burning the cane. In fact, since the laborer is paid time-and-a-half for cutting burned cane, it becomes almost impossible in many cane areas to cut cane unless it is burned. The grower must come to realize that, when the flames start to consume the trash in his fields, they may be also destroying the ability of his soil to produce higher sugarcane yields. He must accept the saving in labor costs and possible use of more fertilizer as compensation for these lower yields.

\section{SUMMARY}

Experiments on handling sugarcane trash were set up at Río Piedras P.R., in the Humid Cane Area, to determine the effect on cane yield and soil properties.

The treatments conducted on 17 consecutive crops of 3 plant canes and 14 ratoons consisted of burying the trash, burning the trash, and aligning it in alternate rows. The principal results were as follows:

1. There were significantly lower yields in tons of sugar per acre when the burned-trash and the aligned-trash treatments were compared. This difference did not become significant until the seventh ratoon of the first cycle.

2. The detrimental effect of burning the trash disappeared with the plowing-up of the ratoon and planting a new cane crop. However, the lower yields associated with burning returned earlier in the ratoons for each new cycle.

3. Burying the cane trash resulted in yields of sugar per acre intermediate between those from aligning the trash and burning. 
4. There was no significant influence on the sucrose content of the cane from any of the trash-handling treatments.

5. Tons of cane per acre were significantly lower when the trash-burned treatment was used as compared to aligning. This difference occurred later in the ratoons and then was found for tons of sugar per acre.

6. Yields of tons of cane per acre associated with burying the trash were intermediate between those from aligning the trash and burning.

7. The possible roles of organic matter and soil aeration are discussed in relation to the rejuvenation of soils under the trash-burned treatment when plowed and replanted.

\section{RESUMEN}

En Río Piedras, Región Lluviosa de Puerto Rico, se llevaron a cabo experimentos para determinar qué efecto tiene la manera de disponer de la paja de la caña de azúcar sobre la producción de caña y las propiedades de los suelos.

Los tratamientos, en 17 cosechas consecutivas, 3 de plantilla y 14 de retoño, consistieron en incorporar la paja al suelo, quemarla, y alinearla en hileras alternas. Los siguientes fueron los resultados más importantes:

1. Los rendimientos de azúcar, en toneladas por acre, fueron significativamente más bajos cuando se quemó la paja, al compararse con los de alineamiento. La diferencia no llegó a ser significativa hasta el séptimo retoño del primer ciclo.

2. El efecto perjudicial de la quema de la paja desapareció al ararse el retoño y sembrarse la caña de nuevo. No obstante, los bajos rendimientos asociados con la quema volvieron a ocurrir más tempranamente en los retoños de cada nuevo ciclo.

3. La incorporación de la paja de la caña al suelo produjo rendimientos de azúcar por acre, que resultaron intermedios entre los producidos cuando se alineó y cuando se quemó.

4. Ninguno de los tres tratamientos para disponer de la paja afectó significativamente el contenido de sacarosa de la caña.

5. La producción de caña, en toneladas por acre, fue significativamente más baja al compararse el tratamiento de quema con el de alineamiento. Esta diferencia se notó más tarde en los retoños, después de lo cual se determinó en términos de toneladas de azúcar por acre.

6. La producción de caña por acre asociada al tratamiento de incorporar la paja al suelo fue intermedia entre la producción cuando se alineó y cuando se quemó la paja.

7. El posible papel que desempeñan la materia orgánica y la aeración del suelo se discuten en relación con la renovación de los suclos cuando después de quemarse la paja se ara y se resiembra. 


\section{LITERATURE CITED}

1. Bonnet, J. A., Abruña, F., and Lugo-López, M. A., Trash disposal and its relation to cane yield, soil, and water losses, J. Agr. Univ. P.R. $34(3)$ : 103-15, 1950.

2. Caribbean Area Office, Annual report of program activities 1963, USDA Agricultural Stabilization and Conservation Service, San Juan, P.R., Jan. 1964.

3. Hardy, F., and Evans, L. J. C., Yields of sugarcane trash, Trop. Agr. 28: 224-5, 1946.

4. Landrau, P., Jr., Lugo-López, M. A., Samuels, G., and Silva, S., Leaving sugarcane trash undisturbed on a lateritic soil compares favorably with currently used trash-disposal methods, J. Agr. Univ. P.R. 88(1): 1-8, 1954.

5. Martínez, M. B., and Lugo-López, M. A., Lack of residual influence from subsoil fertilization of a sugarcane plant crop upon the succeeding ratoon crop, $J$. Agr. Univ. P.R., S8(3): 123-7, 1954.

6. Samuels, G., Sugarcane and the soil, Better Crops 94: 25-6, Dec. 1950.

7. Samuels, G., Alers Alers, S., and Landrau, P., Jr., The application of fertilizers in relation to the handling of sugarcane trash, $J$. Agr. Univ. P.R. \$4(2): 87-91, 1960.

8. Samuels, G., Lugo-López, M. A., and Landrau, P., Jr., Influence on the handling of sugarcane trash on yields and soil properties, Soil Sci. 74(3): 207-15, 1952. 